\title{
The Effectiveness of Work Stress Coping Strategies: An Analysis of Probit Model
}

\author{
THI LIP SAM \\ Faculty of Business Management \\ Universiti Utara Malaysia \\ LIM HOCK EAM \\ Faculty of Economics \\ Universiti Utara Malaysia
}

\begin{abstract}
This study finds that the work stress levels that are faced by ICT personnel range from mild to moderate. The estimated probit model finds that there is personality differentiation in the effectiveness of stress coping strategies. The significant and effective coping strategy is "seeking treatment". The "escape from situation" coping strategy is found to be significant but ineffective. Thus, it is recommended that in alleviating work stress, "seeking treatment" is the best strategy. It is found that the high risk group that have higher work stress are non-Malays, married, field of specialization of accounting/business/ economics, job status of junior management, and less than 2 years of services.
\end{abstract}

\begin{abstract}
ABSTRAK
Kajian ini mendapati tekanan kerja yang dihadapi oleh personel ICT adalah dalam julat ringan sehingga sederhana. Model probit yang dianggarkan menunjukkan bahawa terdapat perbezaan dalam keberkesanan strategi mengatasi tekanan kerja mengikut jenis keperibadian. Strategi mengatasi tekanan kerja yang signifikan dan berkesan adalah "seeking treatment". Strategi "escape from situation" adalah signifikan tetapi didapati tidak berkesan. Maka, adalah dicadangkan dalam mengurangkan tekanan kerja, strategi "seeking treatment" adalah strategi terbaik. Kajian ini juga mendapati kumpulan berisiko tinggi dalam menghadapi tekanan kerja tinggi adalah mereka yang bukan Melayu, berkahwin, dengan pengkhususan perakaunan/perniagaan/ekonomi, status pekerjaan pada tahap pengurusan bawahan, dan tempoh perkhidmatan kurang dari dua tahun.
\end{abstract}

Keyword:

Work stress; personality type; effectiveness of stress coping strategies; probit model; ICT personnel.

\section{INTRODUCTION}

The introduction of ICT into business organizations has offered great promise for an increase in efficiency and productivity. ICT personnel, according to Christian and Oliver (1999),“...have the greatest management challenges and oppor- tunities in modern organizations. Everything is coming their way...". In the era of keen competition and pressure to control costs and improve productivity, computer technology and those who know how to manage it, hold the key to the future (Christian \& Oliver, 1999). In fact, ICT has been widely regarded as a strategic resource for organi- 
zations to stay ahead of their competitors. There is a great demand for ICT personnel with postgraduate degrees as mentioned in the Third Malaysian Outline Perspective Plan: 2001-2010 (OPP3). The numbers of ICT personnel (which consists of system engineers, software developers, system analysts, programmers and other technical support staff) have increased from 88,160 in 1998 to 108,000 in 2000. The Third Malaysian Outline Perspective Plan: 2001-2010 also projected an average annual growth rate of $11 \%$ on the demand for key ICT personnel. Given the growing number of ICT personnel in the workforce in Malaysia and the important role they undertake in organizational development, research focusing on work stress of ICT personnel is imperative.

In Malaysia, research on work stress in a wide variety of professional groups such as teachers, managers, engineers, lawyers, medical personnel and other professionals has been examined. Nevertheless, little attention has been devoted to examining work stress among ICT personnel. The research that exists on this topic mainly focuses on ICT personnel in the United States (Ivancevich, Napier \& Wetherbe, 1983; Weiss, 1983). Mohd Hassan Selamat (1994) did a study on the job stress of ICT employees in Malaysia. Previous researches have found that Malaysian and Singaporean ICT personnel experience high work stress. The stress coping strategies have also been identified (Liang, 1997; Mohd Hassan Selamat, 1994; Ong, 1992). But, little attention is focused on the effectiveness of these coping strategies. As such, using a Probit model, this study aims to estimate the effectiveness of these work stress coping strategies and their interaction effect with personality types. By individual heterogeneity, the high risk group having higher work stress is also estimated. The outcome of this study is expected to help in formulating effective stress management policies. In designing programs that help the ICT personnel to alleviate work stress, the understanding of the effectiveness of coping strategies used is important.

This study consists of six sections. The first section presents the introduction. The second provides a literature review. The third section presents the research questions and hypotheses. The fourth discusses the data and methodology used. The fifth section presents the estimation of results and interpretation and the final section concludes this study.

\section{LITERATURE REVIEW}

Historically, the word stress is derived from the Latin word streingere, which means 'to draw tight'. Psychologist and stress expert, Lazarus (1991), describes stress as the experience of realizing that your situation or environment is taxing your resources and endangering your well being. Work stress is also known as 'occupational stress', 'job stress', or 'stress in organizations'. Work stress is a condition in which the job related factors interact with the worker to disrupt his or her psychological or physiological conditions that cause him or her to deviate from normal functioning (Beehr \& Newman,1978). Selye (1976) introduces a term known as the General Adaptation Syndrome (GAS) to describe how people cope with stress. The first stage is known as alarm reaction where the body's system provides the initial reactions such as adrenal enlargement and gastrointestinal ulcers. This 'Fight-or-Flight' responses to coping with a crisis has provided initial insights into how individuals cope with stress. The second stage of GAS is known as the adaptive stage characterized by the vanishing of the symptoms experienced in the initial stage. Prolonged exposure to stress would cause the loss of adaptation and the third stage is where exhaustion emerges.

In a study conducted by Liang (1997), ICT personnel in Singapore were found to have experienced fairly high stress levels. The findings concur with the findings of Mohd Hassan Selamat's (1994) study on 118 information system personnel in the public sector in Malaysia. He reports that information personnel working in government departments experience a high level of stress that is above the midpoint of the scale. A similar study by Ong (1992), also found that ICT personnel in Singapore are candidates for burnout. Female ICT personnel are more prone to burnout than their male counterparts. 
According to Monat \& Lazarus (1977), coping is an effort to master conditions of harm, threat or challenges. However, Pearlin \& Schooler (1978) refer to coping as the behaviour that protects people from being psychologically harmed by problematic social experiences. Several classifications of coping behavior are suggested in empirical studies. Among them are the adaptive and maladaptive coping strategies (Cooper \& Payne, 1988), control, symptom-management and escape strategies (Latack, 1986); and, problemfocused and emotion-focused strategies (Lazarus \& Folkman, 1984). Pearlin \& Schooler (1978) have distinguished three types of coping which are "(a) responses that modify situation, (b) responses that control the meaning of the situation, and (c) responses that control or minimize the stress response itself." On the other hand, Burke $\&$ Belcourt (1974) suggest that stress is controlled by analyzing the situation and changing the strategy of attack.

The study conducted by Koh (1990), reports that for IT professionals in Singapore, among the strategies adopted to cope with work stress include scrutinizing the problem and attempting to solve it in the best way, and working harder than usual at dealing with the problem. A local study conducted by Fatimah (1985) states that working women cope with stress by time management, delegation and reactive role behaviors. However, among the three strategies, time management is the most frequently used. A similar study conducted by Ungku Norulkamar (1995) on 198 Malaysian employees, identified three types of coping strategies which are control, symptom-management and escape strategies. However, the study found that control strategy (which suggests that employees liked to take charge) was the most frequently used coping strategy as compared to symptom-management and escape strategies. In short, the work stress coping strategies have been clearly identified in the literature. Nevertheless, their effectiveness have yet to be explored.

In terms of personal characteristics, the Type A and Type B person differentiations are the most widely discussed in work stress studies (Cooper \& Marshall, 1976). Caplan \& Jones (1975) find no relationship between Type A and stress at work, as well as no relationship with stress responses. Nevertheless, Caplan et al., (1980) report that the relationship between stress and mental strain are moderated by Type A personality. Type A are people who are task oriented, competitive and have a strong sense of urgency, and they are most likely to adopt control or problem focused strategy (Friedman \& Rosenman, 1974). Ivancevich et al., (1985) found that individuals with personalities such as Type A, locus of control, and self efficacy are found to influence an individual's perception of stress and moderate the stress-outcome relationship. These findings suggest the possible interaction effect between personal characteristics and the effectiveness of stress coping strategies.

Besides personality differentiation, other individual heterogeneity such as age, gender and education are also found to have the same function as an individual's personality in the stress process (Weiss, 1983; Ivancevich et al., 1985). Selecting an appropriate coping strategy and having enough social support could help individuals overcome the negative effects of work stress and enhance the level of individuals' positive outcome (Weiss, 1983). Payne et al. (1988) classify an individual's differences into three categories i.e. genetic, acquired and disposition, which moderates an individual's perception to work stress. The study conducted by Ungku Norulkamar (1995) on 198 employees showed that Malay employees used escape and symptom-management strategies more frequently than Chinese employees. Female employees also used the escape strategy more frequently than their male counterparts. Employees with post-graduate degree used control strategy more frequently in coping with stress. However her study does not concur with Anderson (1976), that those who have experienced high levels of stress differ substantially in the coping patterns than those with moderate or mild stress. Malaysian employees who experience different stress 
levels use control, escape and symptom-management strategies at about the same frequency (Ungku Norulkamar, 1995).

In summary, previous studies on work stress have focused on the stress levels, the coping strategies used, personality type differentiation and individual heterogeneity. The effectiveness of these coping strategies have been ignored. Thus, this study attempts to investigate the effectiveness of coping strategies, with relation to personality type and other individual heterogeneity factors.

\section{RESEARCH QUESTIONS AND HYPOTHESIS}

\section{Research Questions}

This research aims to investigate the following research questions:

1. Are there any differences on the use of stress coping strategies between type A and type B persons?

2. Are there any differences on the use of stress coping strategies between groups that face different stress levels?

3. For the five stress coping strategies, what are their effectiveness?

4. Are there any interactive effects between the effectiveness of stress coping strategies and personality types?

5. What is the role of individual heterogeneity in determining the effectiveness of stress coping strategies?

6. Which group has the highest risk of having high work stress?

\section{Hypothesis}

For the first and second research questions, the 'two population independent' t-test is used to answer them. It is expected that individuals displaying type A personality would cope with stress differently from those with type B personality. For instance, individuals with type A personality, who possess the "take charge" attitude and are task oriented, are expected to use the control strategy more frequently. Thus,

a. Hypothesis 1:

There are differences in the frequency of coping strategies used by personality types.

Since individuals react to stress differently, according to how severely they perceive the stressful situation, we expect the use of stress coping strategies are different by work stress level faced. Thus,

b. Hypothesis 2:

There are differences in the frequency of coping strategies used by the level of work stress faced.

The effectiveness of coping strategies refers to its ability to reduce the probability of having higher work stress. A probit model is estimated to assess this effectiveness, and to answer the third to sixth research questions. We expect, if the coping strategy is effective, it should have a negative and significant impact on the probability of having higher work stress. Thus,

c. Hypothesis 3:

The coping strategies have significant negative impact on the probability of having higher work stress.

Since there are perceived differences on work stress faced among different individuals, we expect that individuals with personality type A, with task-oriented and take control personalities, will find stress coping strategies, such as facing challenges and seeking treatment, are more effective than escaping from the situation. Similarly, due to differences in perceived work stress, individual heterogeneity is expected to have significant role in determining the effectiveness of stress coping strategies. Thus,

d. Hypothesis 4

There is interactive effect between the effectiveness of stress coping strategies and personality types.

e. Hypothesis 5

Individual heterogeneity has important influence in determining the effectiveness of stress coping strategies. 


\section{DATA AND METHODOLOGY}

\section{Data}

The data used in this study are taken from Thi (2001). They consist of 98 ICT personnel employed in a number of companies dealing with technology-related industrial products and services. The data provide information on work stress faced (using the General Physical Health Questionnaire), personality types (using Bortner's Pattern A Behaviour Scale), stress coping strategies (using 32 items developed by Latack(1986)). Appendix A provides explanation to the sampling process and questionnaire design

\section{Methodology \\ Classification of personality types and coping strategies}

Hierarchical cluster analysis utilizing the Ward method is used to group respondents into Type A and Type B personalities. Factor analysis is used to classify the items on stress coping strategies. In order to assess the consistency and reliability of the measurement scales, a reliability test using Cronbach Coefficient Alpha is undertaken. The acceptable reliability coefficient or alpha is based on Helmstadter's (1964) standard that is 0.5 and above. Appendix B provides detail classification of these coping strategies.

\section{Classification of work stress faced}

In this sample, after averaging the items on work stress, the work stress levels found are classified into three categories, i.e., mild, moderate and high. The categories are divided based on the equal distribution of the 5-point Likert scale (in a scale of $1=$ never, $2=$ seldom, $3=$ sometimes, $4=$ very often, $5=$ almost all the time). Those with scores of 1 to 1.67 are considered as having mild work stress, 1.68 to 3.34 as having moderate work stress, and 3.35 to 5.00 as having high work stress.

\section{The effectiveness of coping strategies and personality types}

To measure the effectiveness of coping strategies and its interactive effect with personality types on the probability of having higher work stress, a probit model is estimated. The probit model is specified as below:

Given a Latent variable model: $Y_{i}^{*}=\beta^{`} X_{i}+u_{i}$

where

$\mathrm{u}_{\mathrm{i}}=$ white noise error term ; $\mathrm{X}_{\mathrm{i}}=$ matrix of independent variables

$\mathrm{Y}_{\mathrm{i}}=1$ (moderate work stress) if $\mathrm{Y}_{\mathrm{i}}^{*}>0 ; \mathrm{Y}_{\mathrm{i}}=0$ (mild work stress) if $Y_{i}^{*} / ., \leq 0$

The probability of having moderate work stress can be specified as below

$$
\begin{aligned}
& \operatorname{Prob}(Y=1 \mid X)=\operatorname{Prob}\left(Y^{*}>0\right)=\operatorname{Prob}\left(\beta^{\prime} X+\right. \\
& \begin{aligned}
u>0) & =\operatorname{Prob}\left(\mathrm{u}>-\beta^{`} X\right) \\
& =\operatorname{Prob}\left(\mathrm{u}<\beta^{\prime} X\right)=\Lambda\left(\beta^{\prime} \mathrm{X}\right)
\end{aligned}
\end{aligned}
$$

Assuming that the error term follows a normal distribution, we have the probit model. The model will be estimated using Maximum Likelihood estimation method.

\section{RESULTS AND ANALYSIS}

\section{Descriptive Statistics}

The demographic data of 98 respondents who participated in this research are summarized in Table 1. The descriptive statistics show the age group of above $50(1 \%)$, and 41 to $50(8.2 \%)$ are being less represented. This also happens in other variables such as ethnic group of Indian (3.1\%) and others (3.1\%). As such, for further analysis, we combine these categories. Appendix C provides the definition and measurement of variables that are used in the estimation of the probit model. 
Table 1

Respondents' Characteristics

\begin{tabular}{|c|c|}
\hline & $\%$ \\
\hline \multicolumn{2}{|l|}{ Gender: } \\
\hline Male & 53.10 \\
\hline Female & 46.90 \\
\hline \multicolumn{2}{|l|}{ Age group: } \\
\hline$>25$ & 28.60 \\
\hline 25 to 30 & 32.70 \\
\hline 31 to 35 & 15.30 \\
\hline 36 to 40 & 14.30 \\
\hline 41 to 50 & 8.20 \\
\hline above 50 & 1.00 \\
\hline \multicolumn{2}{|l|}{ Ethnic group: } \\
\hline Malay & 41.80 \\
\hline Chinese & 52.00 \\
\hline Indian & 3.10 \\
\hline Others & 3.10 \\
\hline \multicolumn{2}{|l|}{ Marital Status: } \\
\hline Single & 64.30 \\
\hline Married without children & 9.2 \\
\hline Married with children & 26.50 \\
\hline \multicolumn{2}{|l|}{ Education level: } \\
\hline $\mathrm{SPM} / \mathrm{MCE} / \mathrm{GCE}$ & 8.20 \\
\hline STPM/HSC/ A level & 2.00 \\
\hline Diploma & 14.30 \\
\hline Bachelor's degree or equivalent & 65.30 \\
\hline Master & 10.2 \\
\hline $\mathrm{PhD}$ & 0.00 \\
\hline \multicolumn{2}{|l|}{ Specialization field: } \\
\hline Business/Economics/Accounting & 16.30 \\
\hline Sciences/Computer Science/IT & 59.20 \\
\hline Engineering & 6.10 \\
\hline Arts & 4.10 \\
\hline Others & 14.30 \\
\hline
\end{tabular}


(continued)

\begin{tabular}{|l|r|}
\hline & $\%$ \\
\hline Working experience: & \\
> 2 years & 35.70 \\
3 to 6 years & 30.60 \\
7 to 10 years & 7.10 \\
$>$ 10 years & 26.50 \\
\hline Length of service in current comp. & \\
> 2 years & 57.10 \\
3 to 6 years & 24.50 \\
7 to 10 years & 6.10 \\
> 10 years & 12.20 \\
\hline Management level: & \\
Senior & 8.20 \\
Middle & 23.50 \\
Junior & 68.40 \\
\hline Personality type & \\
Type A & 48.00 \\
Type B & 52.00 \\
\hline
\end{tabular}

na $=$ not applicable

Table 2

Work Stress Faced

\begin{tabular}{|l|c|c|c|}
\hline Mean & Std deviation & Min & Max \\
\hline 1.8367 & 0.37151 & 1 & 2 \\
\hline
\end{tabular}

From Table 2, it is found that the average work stress faced in this sample is 1.8367 with standard deviation of 0.37151 , a maximum value of 3 and a minimum value of 1 . As such, according to the classification, the sample has only 2 categories of work stress faced, i.e., mild (1.00 $1.67)$ and moderate $(1.68-3.34)$. The following probit analysis is based on these two categories of work stress. 
Table 3

Personality Type and Coping Strategies

\begin{tabular}{|l|l|c|c|c|c|}
\hline Coping Strategies & Personality & Mean & df & t value & p-value \\
\hline Face challenges & $\begin{array}{c}\text { Type A } \\
\text { Type B }\end{array}$ & $\begin{array}{l}3.54 \\
3.76\end{array}$ & 96 & -1.797 & 0.08 \\
\hline $\begin{array}{l}\text { Physical and } \\
\text { emotional relief }\end{array}$ & $\begin{array}{c}\text { Type A } \\
\text { Type B }\end{array}$ & $\begin{array}{l}3.06 \\
3.14\end{array}$ & 88.79 & -0.597 & 0.55 \\
\hline Escape from situation & Type A & 3.04 & 96 & -0.927 & 0.36 \\
& Type B & 3.08 & & & \\
\hline Seek treatment & $\begin{array}{l}\text { Type A } \\
\text { Type B }\end{array}$ & $\begin{array}{l}2.35 \\
2.49\end{array}$ & 96 & -1.038 & 0.30 \\
\hline Ignore the situation & Type A & 2.97 & 96 & -1.177 & 0.24 \\
\hline
\end{tabular}

Note:

1. The difference in number of degree of freedom is due to the validity of equal variances assumption on the two population t-test, which is tested by Levene's test for equality of variances.

\section{Coping Strategies and Personality Types}

For the two population independent t-test, the pvalues of the five coping strategies are all above the significant level of 0.05 (Table 4). The t-test results show that on average, both Type A and Type B personalities use the five coping strategies at about the same frequency. Thus, the sample does not provide sufficient evidence that there are differences in the frequency of coping strategies used by personality types.

\section{Coping Strategies and Stress Levels}

T-test is also undertaken to test for significant differences in the use of coping strategies among ICT personnel who experienced different levels of stress.

T-test results show that respondents who have experienced mild or moderate stress use 'seeking physical and emotional relief', 'escaping from situation', 'seeking treatment' and 'ignoring the situation' strategies at about the same frequency. Interestingly though, respondents who experience mild stress differ significantly in using 'face challenges' strategy in coping with work stress (with p-value of 0.008). They use facing challenges strategies less frequently than respondents who experience moderate stress. Thus, the sample provides sufficient evidence that those having higher work stress, use 'facing challenges' coping strategy more frequently compared to those having lower work stress.

\section{The Analysis of Probit Model}

The above hypothesis tests on work stress coping strategy used (table 3 and table 4) are performed in such a way that the influences of other independent variables are not controlled. To control these influences, a probit model is estimated to 
Table 4

Levels of Stress and Coping Strategies

\begin{tabular}{|l|c|c|c|c|c|}
\hline \multicolumn{1}{|c|}{ Coping Strategies } & Stress level & Mean & $\mathbf{d f}^{1}$ & t value & p-value \\
\hline Face challenges & $\begin{array}{c}\text { Mild stress } \\
\text { Moderate stress }\end{array}$ & $\begin{array}{l}3.30 \\
3.72\end{array}$ & 96 & -2.700 & $0.008^{* *}$ \\
\hline $\begin{array}{l}\text { Physical and emotional } \\
\text { relief }\end{array}$ & $\begin{array}{c}\text { Mild stress } \\
\text { Moderate stress }\end{array}$ & $\begin{array}{l}3.22 \\
3.10\end{array}$ & 46.51 & 1.155 & 0.254 \\
\hline Escape from situation & $\begin{array}{c}\text { Mild stress } \\
\text { Moderate stress }\end{array}$ & $\begin{array}{l}2.93 \\
3.14\end{array}$ & 26.51 & -1.205 & 0.239 \\
\hline Seek treatment & $\begin{array}{c}\text { Mild stress } \\
\text { Moderate stress }\end{array}$ & $\begin{array}{l}2.38 \\
2.43\end{array}$ & 96 & -0.318 & 0.751 \\
\hline Ignore the situation & $\begin{array}{c}\text { Mild stress } \\
\text { Moderate stress }\end{array}$ & $\begin{array}{c}3.25 \\
3.03\end{array}$ & 96 & 1.010 & 0.315 \\
\hline
\end{tabular}

Note:

1. The difference in number of degree of freedom is due to the validity of equal variances assumption on the two population t-test which is tested by Levene's test for equality of variances.

2. ** Significant at $1 \%$ level

assess the direct and interactive effect (with personality types) of work stress coping strategy towards work stress levels, after having the control variables of ethnic, gender, marital status, fields of specialization, management levels, working experiences, length of services, and education levels.

To accommodate the heteroscedasticity that always exists in cross section data, the probit model is estimated using White heteroscedasticityconsistent estimator. The results are presented in Table 5. Appendix $\mathrm{C}$ provides a definition and measurement of the variables. Appendix D provides details of the estimated probit model. To accommodate the influence of multicollinearity that may cause the significant variable to become insignificant, all insignificant variables will be tested again jointly on a restriction test. Table 6 summarizes the restriction test result. It is found that the individually insignificant variables are insignificant jointly as well. Thus, the influence of multicollinearity should be at its minimum.
The Wald test on overall fit of estimated model is found significant with p-value of 0.0031 . The pseudo $\mathrm{R}^{2}$ is 0.4244 .

\section{The Personality Types and Stress Coping Strategies}

Type A persons are people who are task oriented, competitive, strive for high achievement and have a strong sense of urgency. They are characterized by the need to control, aggressiveness and competitiveness. Whereas, type B persons are people with characteristics that are just the opposite of type A persons. As such, we expect the effectiveness of stress coping strategies to be different between these two types of personalities. For instance, for type A persons with the need to control, the facing challenge strategy is expected to be more effective compared to the escape strategy.

From Table 5, at 5\% significant level, in terms of the effect on probability of having higher 
Table 5

Estimated Probit Model

\begin{tabular}{|c|c|c|}
\hline Variables & $\begin{array}{l}\text { Co-efficient } \\
\text { Estimated }\end{array}$ & P-value \\
\hline D type & 0.3942 & 0.897 \\
\hline chanll1 & 0.1188 & 0.818 \\
\hline relief & -0.3904 & 0.295 \\
\hline escape1 & 1.4251 & $0.042 * *$ \\
\hline treatm1 & -1.1592 & $0.034 * *$ \\
\hline ignore1 & -0.2876 & 0.555 \\
\hline typeCh1 & 0.3882 & 0.525 \\
\hline Type Rel & 0.0007 & 0.999 \\
\hline Type Esc & -1.3928 & $0.052 *$ \\
\hline Type Tm & 1.1323 & 0.125 \\
\hline Type Ig & 0.1114 & 0.851 \\
\hline D ethnic & 1.4158 & $0.040 * *$ \\
\hline D gender & -0.3469 & 0.570 \\
\hline Dmar1 & 0.6041 & 0.340 \\
\hline Dmar2 & 2.6322 & $0.002 * * *$ \\
\hline Dfield1 & -1.2403 & $0.032 * *$ \\
\hline Dfield2 & -0.3039 & 0.711 \\
\hline Djobs1 & 0.8207 & 0.231 \\
\hline Djobs2 & -0.5926 & 0.245 \\
\hline Djobs3 & -1.5875 & $0.044 * *$ \\
\hline Yrs work & 0.2574 & 0.418 \\
\hline Dserv1 & -1.8574 & $0.004 * * *$ \\
\hline Dserv3 & -2.9667 & $0.005 * * *$ \\
\hline Edu & 0.1365 & 0.562 \\
\hline
\end{tabular}


(continued)

\begin{tabular}{|l|c|c|}
\hline Variables & $\begin{array}{c}\text { Co-efficient } \\
\text { Estimated }\end{array}$ & P-value \\
\hline Dage1 & 0.6196 & 0.301 \\
Dage2 & 1.2843 & 0.160 \\
Dage3 & 0.4272 & 0.577 \\
Dage4 & -0.6525 & 0.569 \\
constant & 0.3704 & 0.886 \\
\hline
\end{tabular}

Notes:

1. $*=$ significant at $10 \%$ level; $* *=$ significant at $5 \%$ level; $* * *$ significant at $1 \%$ level

2. Wald test on overall fit of model estimated: $p$-value $=0.0031$

3. Pseudo R2 $=0.4244$

Table 6

Restriction Test on Individually Insignificant Variables

\begin{tabular}{|l|c|}
\hline Variables & P-value \\
\hline Dtype chanll1 relief ignore1 typeCh1 typeRel typeTm typeIg & 0.1220 \\
Dgender yrswork edu Dage1 Dage2 Dage3 Dage4 & 0.2849 \\
Dtype chanll1 relief ignore1 typeCh1 typeRel typeTm typeIg & 0.1013 \\
Dgender yrswork edu Dage1 Dage2 Dage3 Dage4 & \\
\hline
\end{tabular}

work stress, the coping strategies of 'escape from situation' (escape1) and 'seek treatment' (treatm1) are found to be significant with the positive and negative impacts respectively. The personality type (Dtype) alone is found insignificant. Nevertheless, the personality type is found to have a weak significant (with p-value of 0.052) impact through interaction with 'escape from situation' indirectly (typeEsc). Thus, in order to evaluate the effectiveness of work stress coping strategies (in terms of probability of having higher work stress), the personality type does matter.

Since the probit model is in fact a nonlinear function and the stress coping strategies are continuous variables, simulation is used to evaluate the impact of the stress coping strategies on the probability of having higher stress. The simulation is done by holding other variables at their mean value respectively.

Graph 1 shows simulation of the impact of 'escape from situation' coping strategy (escape1) on probability of having higher work stress. Graph 1 clearly shows that the increasing use of 'escape from situation' strategy will only increase the probability. With the scale of 1 being never, 2 being seldom, 3 being sometimes, 4 being very often, and 5 being almost all the time, the impact is highest from 1 to 2 ( the steepest slope). We can 
conclude that the 'escape from situation' strategy is not only ineffective; in fact, the use of it will increase the probability of having higher work stress.

Graph 2 shows simulation of the impact of using escape coping strategy between two different personality types. From the scale of 1 (never use escape strategy) to the scale of 4 (very often use of escape strategy), the differences in the probability of having higher work stress between these two-personality types narrow down progressively. The slope of the curve represents the impact of using escape strategies towards probability of having higher work stress. The positive slope means the ineffectiveness of escape coping strategy. For personality type A, initially, there is a lower probability of having higher work stress compared to personality type B. Nevertheless, if the type A persons increase the use of escape strategy, this gap narrows. This suggests that for type A persons, the use of escape strategy will increase the probability of having higher work stress at a rate that is higher than type B persons.

Hence, for type A persons who are aggressive and competitive, if they use the escape coping strategy, then it contradicts with their personal characteristics. For instance, trying to separate themselves from the work stress, and telling themselves that time will take care of stressful situations. These escape strategies are not only ineffective, but will significantly increase the probability of having higher work stress at a faster rate compared to type B persons. Clearly, personality influences the effectiveness of stress coping strategy. The escape strategy is not an effective strategy for both type personalities, especially for type A persons that always need to be in control.

\section{Graph 1}

The Effect of 'Escape from Situation' Strategy on Probability of Having Higher Work Stress

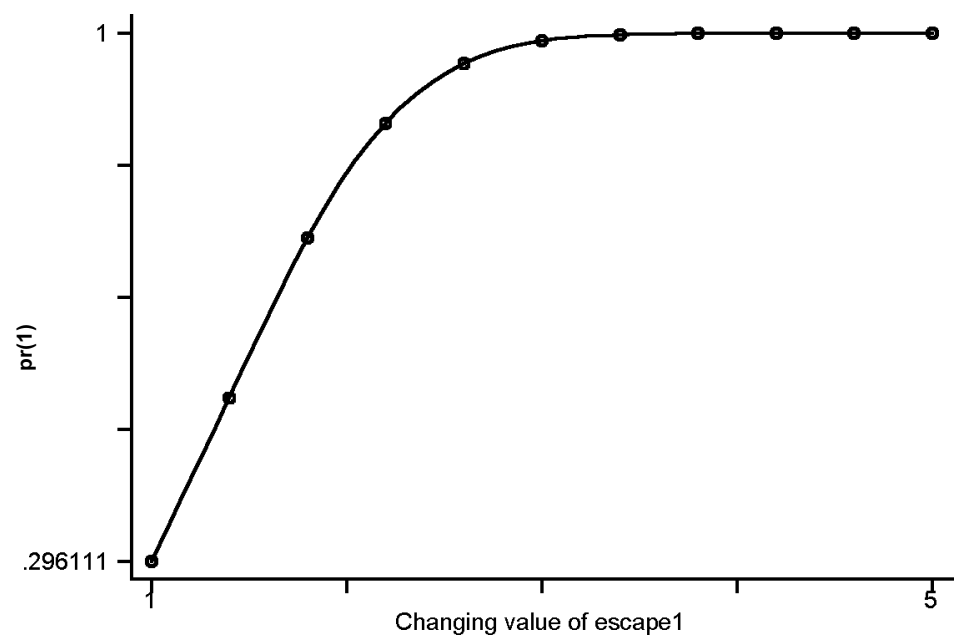

Graph 3 presents the effect of 'seeking treatment' coping strategy (treatm1). 'Seeking treatment' is found to be effective in reducing the probability of having higher work stress. The increase use of this strategy will significantly reduce the probability of having higher work stress. 
Graph 2

The Effect of 'Escape from Situation' Strategy on Probability of Having Higher Work Stress by Personality Types

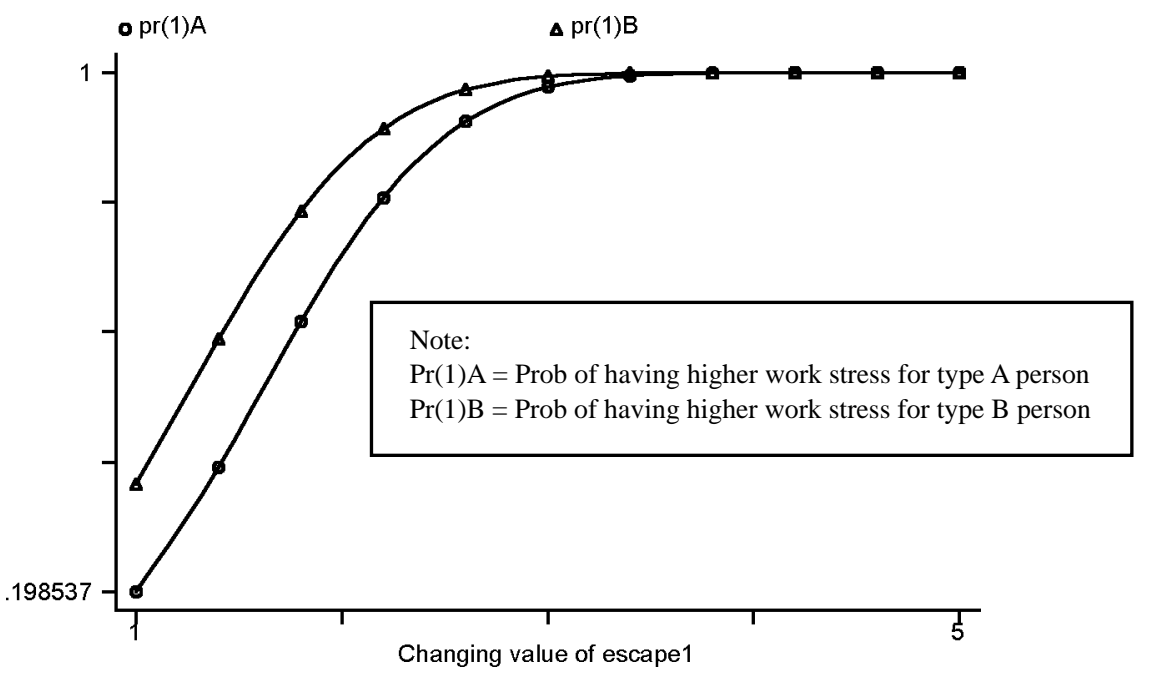

\section{Graph 3}

The Effect of 'Seeking Treatment' Strategy on Probability of Having Higher Work Stress

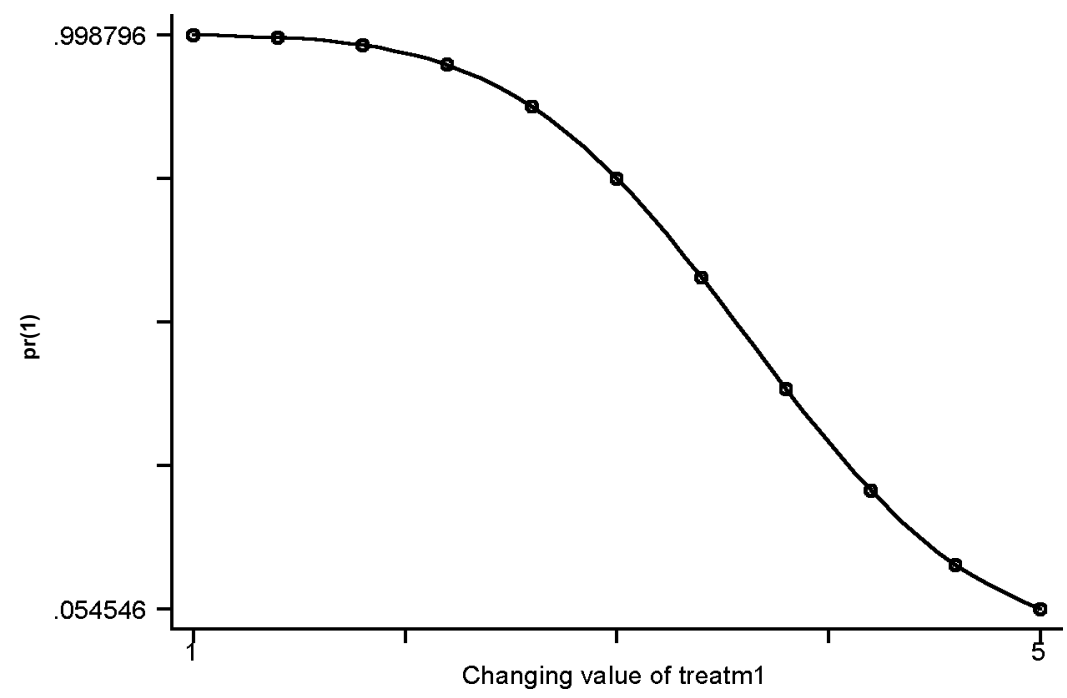

There is no significant interactive effect between this coping strategy and personality types as shown by the p-value of t-test on the interactive variable of seeking treatment strategy and personality (type Tm) in Table 5 . 
In short, after controlling the influence of other demographic variables, only the escape and seeking treatment coping strategies are found to have influence on the probability of having higher work stress. At 5\% significant level, the coping strategy of 'seeking treatment' is found to be significant and effective. Whereas, the 'escape from situation' coping strategy is found to be significant but not effective. Other coping strategies are found insignificant which means that they are not effective in reducing the probability of having higher work stress.

\section{The Individual Heterogeneity}

The estimated probit model also suggests the importance of individual heterogeneity in influencing the probability of having higher work stress. From Table 5, it is can be seen that ethnicity (Dethnic), marital status(Dmar2), field of specialization (Dfield1), job status (Djobs3), and length of service (Dserv1 and Dserv3) have a significant influence on the probability of having higher worker stress, at 5\% significant level. Since all the significant variables are dummies, their impact can be evaluated at discrete changes from zero to one, while holding other variables at their mean values respectively. Table 7 below presents the impact.

Table 7

The Effect of Discrete Change (0 to 1) on Probability of Having Higher Work Stress

\begin{tabular}{|c|c|}
\hline Variable & Effect (0 to 1) \\
\hline $\begin{array}{c}\text { D ethnic }[0=\text { Malay; } 1=\text { non-Malay }] \\
\text { Dmar2 }[1=\text { married with children }] \\
{[\text { base }=\text { single] }}\end{array}$ & 0.0896 \\
\hline $\begin{array}{c}\text { Dfield1 }[1=\text { science/IT] } \\
{[\text { base }=\text { account/business/eco }]}\end{array}$ & 0.1115 \\
\hline $\begin{array}{c}\text { Djobs3 }[1=\text { senior management }] \\
{[\text { base }=\text { junior management }]}\end{array}$ & -0.0752 \\
\hline $\begin{array}{c}\text { Dserv1 }[1=3-6 \text { year service }] \\
{[\text { base }=<3 \text { year service }]}\end{array}$ & -0.3028 \\
\hline $\begin{array}{c}\text { Dserv3 }[1=>10 \text { year service }] \\
{[\text { base }=<3 \text { year service }]}\end{array}$ & -0.2947 \\
\hline
\end{tabular}

From Table 7, it is clear that being nonMalay and married with children will result in having a higher probability of having higher work stress. Whereas, being in the field of science/IT, senior management, 3-6 year or more than 10 years of services will reduce the probability of having higher work stress. In short, from the individual heterogeneity point of view; a non-Malay, married with children, specialization field of accounting/business/economics, job status of 
junior management, less than 2 years of services; is identified as a high risk group of having higher work stress.

\section{The Individual Heterogeneity and Its Impact Towards Effectiveness of Coping strategies}

The significant of t-test (Table 5) shows the importance of certain individual heterogeneity in influencing the probability of having higher work stress. These dominant individual factors also have their implications on the effectiveness of stress coping strategies. For instance, the effectiveness of seeking treatment strategy may differ among Malays and non-Malays. Non-Malays may find that the use of seeking treatment strategy is effec- tive but it may not be as effective for their Malay counterparts.

To assess the impact of individual heterogeneity on the effectiveness of stress coping strategies, a simulation is used to evaluate the impact of the stress coping strategies on the probability of having higher stress by different individual heterogeneity. The simulation is done by holding other variables at their mean value respectively. Simulation is only done on the seeking treatment strategy that is found to be significant and effective. The slope of the simulated curve for different characteristics of individual heterogeneity will reflect the impact of this individual heterogeneity on the effectiveness of stress coping strategies. Steeper slope implies reduced probability of having higher work stress at a faster rate. It also implies effective stress coping strategy.

\section{Ethnicity}

\section{Graph 4}

The Implication of Ethnicity on the Effectiveness of Seeking Treatment Strategy

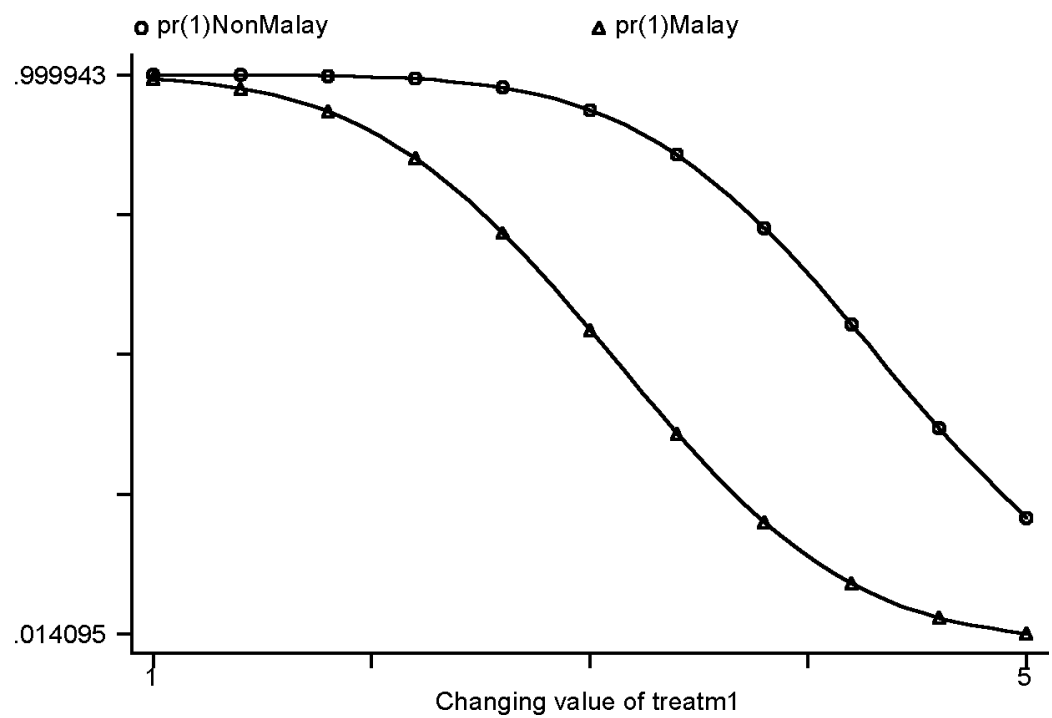

From Graph 4, it is found that as more seeking treatment strategy is used, the probability of having higher work stress is reduced. Neverthe- less, for Malays, the probability is reduced at a rate that is much higher than non-Malays. Initially, on the scale of 1 for seeking treatment strategy, 
both have an almost similar probability. As the use of seeking treatment increases, the gap in the probability increases. Thus, the seeking treatment strategy is found to be more effective for Malays compared to nonMalays.

\section{Marital Status}

\section{Graph 5}

The Implication of Marital Status on the Effectiveness of Seeking Treatment Strategy

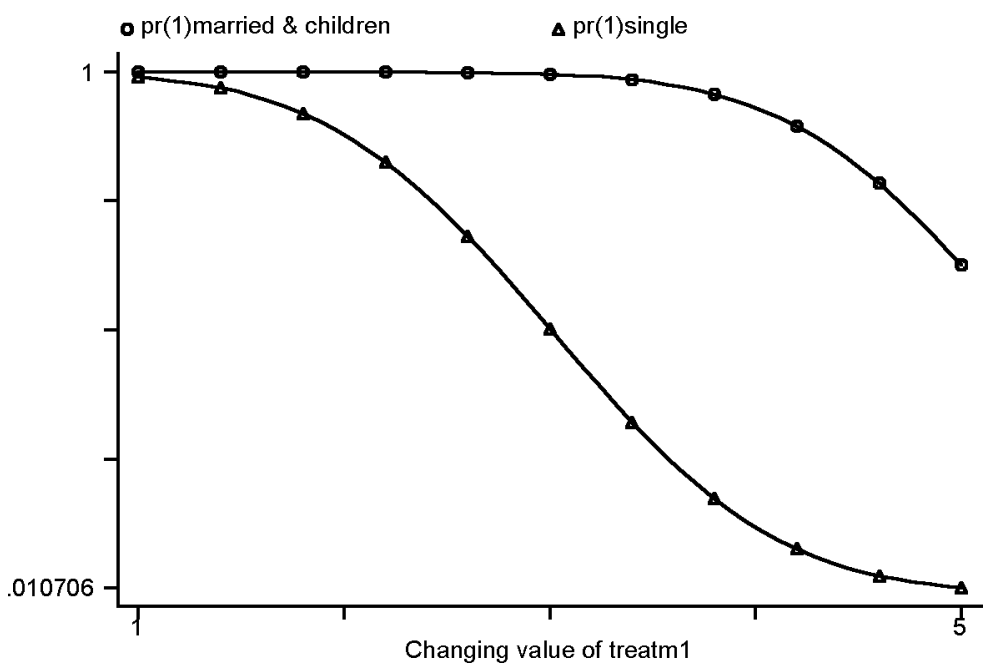

Graph 6

The Implication of Specialization on the Effectiveness of Seeking Treatment Strategy

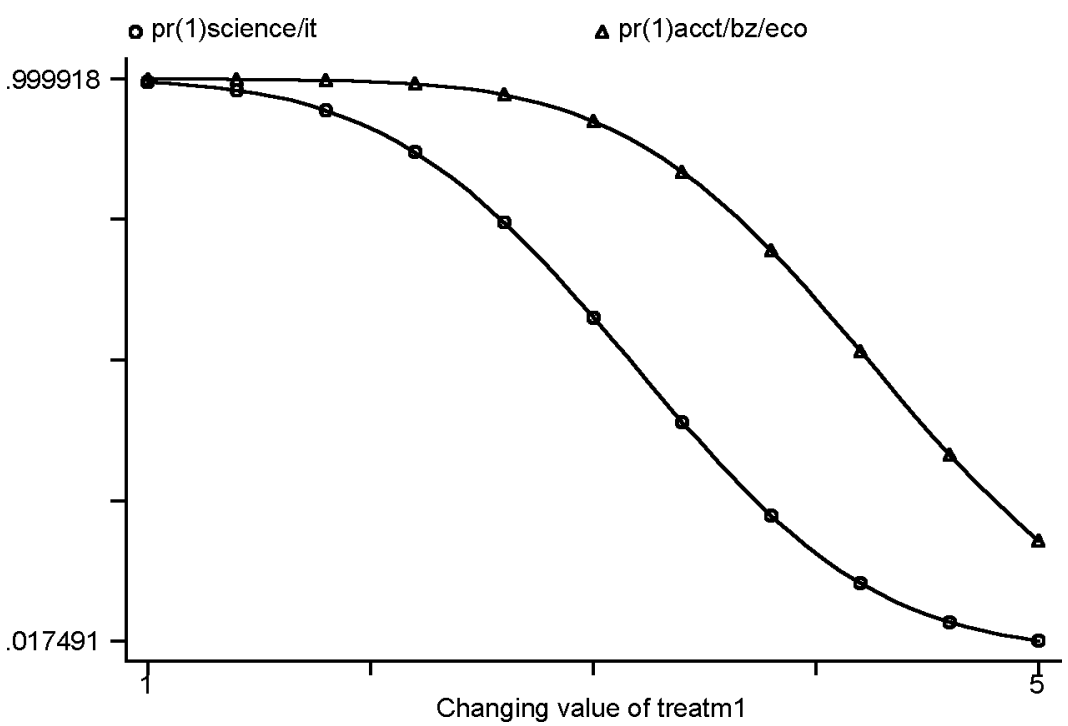


From Graph 5, it is found that marital status has a large impact on the effectiveness of seeking treatment strategy. For singles, the use of seeking treatment strategy will reduce the probability of having higher work stress at a rate that is much faster than those married with children. This is reflected by the steeper slope of the simulated curve for those who are single compared to those married with children.

\section{Field of Specialization and Job Status}

From Graphs 6 and 7, we find that the field of specialization and job status of the individual influence the effectiveness of the seeking treatment strategy in reducing the probability of having higher work stress. For those with science or information technology background, the seeking treatment is more effective compared to those with accounting/ business/economics background. For those in the senior management level, the seeking treatment is more effective as compared to those in the junior management level. Nevertheless, their impact is not as obvious as marital status.

\section{Graph 7}

The Implication of Job Status on the Effectiveness of Seeking Treatment Strategy

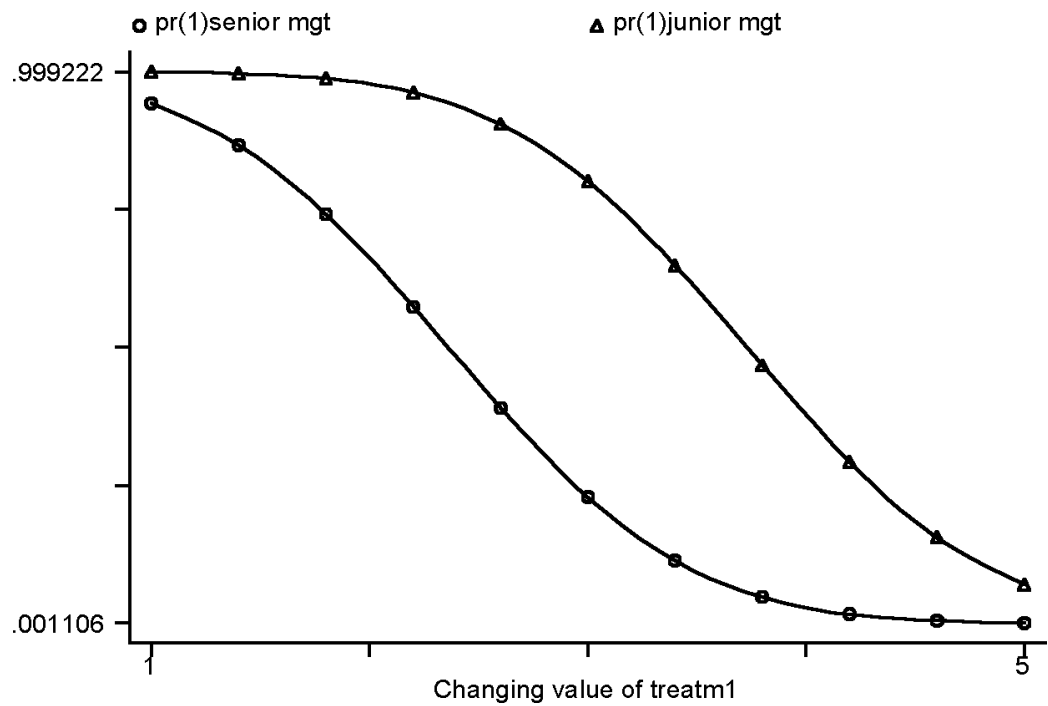

\section{Length of Services}

From Graph 8, we find that for those having more than 10 years of service, the use of seeking treatment strategy is more effective as compared to those with less than 6 years of service. The slope is steeper for those with more than 10 years of service. This steeper slope implies the increased use of seeking treatment strategy will reduce the probability of having higher work stress at a rate faster than others.

In short, we find that ethnicity, marital status, field of specialization, job status and length of service have an impact on the effectiveness of seeking treatment work stress coping strategy. This role of heterogeneity should be taken into consideration when recommending the seeking treatment strategy to ICT personnel. 


\section{Graph 8}

The Implication of Length of Service on the Effectiveness of Seeking Treatment Strategy

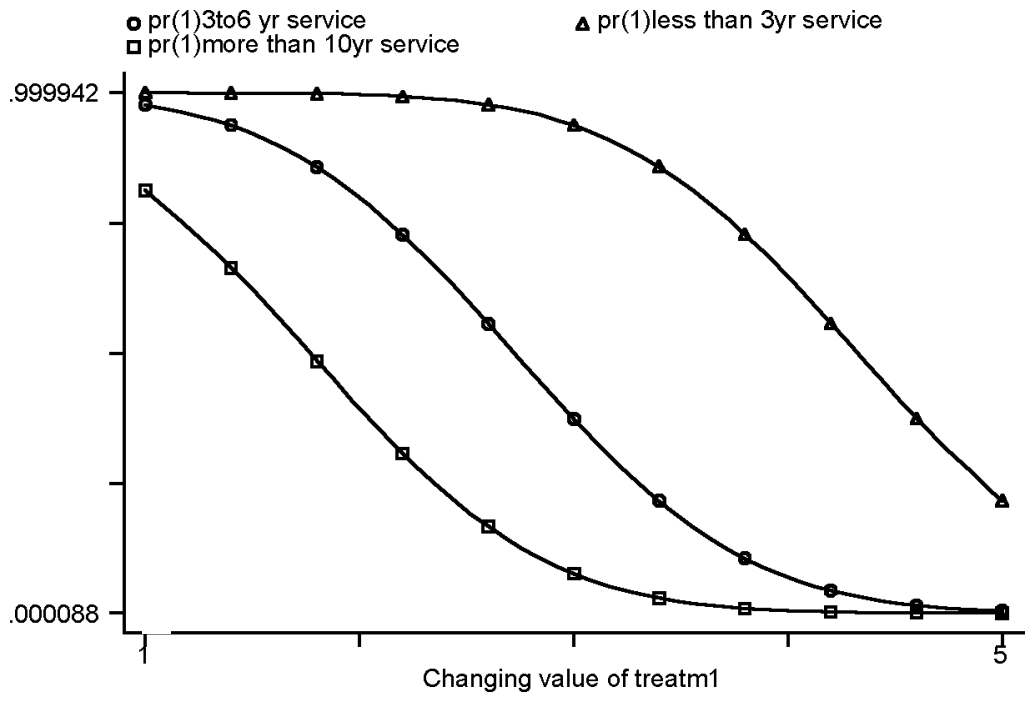

\section{CONCLUSION}

Overall, it is found that the work stress level that ICT personnel faced in this study ranges from mild to moderate. This result contradicts what has been found by previous researches done on Singapore and Malaysia ICT personnel. Using t-test on means difference without controlling the influence of other variables, the results do not support the hypothesis that there is a difference in the coping strategies used by ICT personnel based on different personalities. The respondents which comprise of ICT personnel with Type A and Type B personalities do not differ in their usage of the five coping strategies identified in this study. This finding supports Caplan \& Jones (1975), that there is no relationship between stress and stress responses. It contradicts with Caplan et al.,(1980), Freidman \& Rosenman (1974), and Ungku Norulkamar (1995). Nevertheless, using the estimated probit model, this study found that there are interactive effects between personality types and coping strategies in influencing the probability of having higher work stress. For type B per- sons, the effect of coping strategies is found to be much stronger than type A persons. As such, it is recommended that the policies formulated to alleviate work stress should be made aware that there are personality differentiation in which the effectiveness of stress coping strategies are moderated by personality types.

In terms of the probability of having higher work stress, the estimated probit model shows that the effective coping strategy is 'seeking treatment'. The 'escape from situation' coping strategy is not only ineffective, but it will increase the probability of having higher work stress. There is an interactive effect between escape strategy and personality types. This interactive effect is weakly significant. The ineffective effect of the escape coping strategy is more prominent for type A persons (compared to type B persons). Other stress coping strategies are found to be not significant and do not have any interactive effect with personality types. Thus, it is suggested that the company should encourage its employees to seek treatment in reducing the work stress that they face. Facilities such as providing professional 
counseling and stress management training are imperative. Escaping from work stress will make the situation even worse. The best strategy is 'seeking treatment'.

The estimated probit model also suggests the importance of individual heterogeneity. The ethnicity, marital status, field of specialization, job status, and length of service are found to influence significantly on the probability of having work stress. They also have impact on the effectiveness of 'seeking treatment' work stress coping strategy. It is found that the high risk group that has higher work stress are those of nonMalays, married with or without children, field of specialization in accounting/business/economics, job status of junior management, and less than 2 years of service. Thus, it is recommended that extra focus should be put on this high risk group. This high risk group should be given more attention by management, such as being given the priority for attending work stress management training. Identification of this high risk group will help the company to target the appropriate group to prevent its employees from suffering high work stress.

The findings of this study may be taken into consideration when dealing with work stress for the benefit of the employees as well as the organizations. Nevertheless, several limitations are inherent in this study. First, this study is exploratory in nature. Second, convenient sampling method is utilized in this study. Third, the crosssectional nature of this study made it difficult to draw causal inferences about the relationships among various variables with special references to the measure of stress levels. One avenue for future research is to replicate the study using longitudinal data.

\section{REFERENCES}

Anderson, C. R. (1976). Coping behaviors as intervening mechanisms in the inverted-u: Stress performance relationship. Journal of Applied Psychology, 61 (1), 30-40.
Beehr, T. A. \& Newman, J. E. (1978). Job stress, employee health and organizational effectiveness: A facet analysis model and literature review. Personal Psychology, 31, 665-697.

Bortner, R. W. (1969). A short rating scale as a potential measure of pattern behaviour. Journal of Chronic Disease, 22 (2), 87-91.

Burke, R. J. \& Belcourt, M. L. (1974). Managerial role strain and coping responses. Journal of Business Administration, 5 (1), 55-68.

Caplan, R. D. \& Jones, K. W. (1975). Effects of workload, role ambiguity and type A personality on anxiety, depression and heart rate. Journal of Applied Psychology, 60 (b), 713719.

Caplan, R. D., Cobb. S., French, J. R.D., Harrison, R. V. \& Pinneau, S. R. (1980). Job demands and worker Health. Ann Arbor: Survey Research Center.

Christian, K. \& Oliver, V. (1999). Effects of implementation of information technology on employees, strain and job satisfaction: A context-dependent approach. Work and Stress, 34(4), 341-363.

Cooper, C. L. \& Marshall, J. (1976). Occupational sources of stress: A review of the literature relating to coronary heart disease and mental health. Journal of Occupational Psychology, $49,11-28$.

Cooper, C. L. \& Payne, R. (1988). Causes, coping and consequences of Stress at Work. Chichester: John Wiley.

Fatimah Abdullah (1985). Wanita dan pekerjaan: Satu analisis konflik peranan. Akademika, 27 (Julai), 77-93. 
Friedman, M. \& Rosenman, R. H. (1974). Type A behaviour and your heart. Greenwich, Connecticut : Fawcett Press.

Helmstadter, G. C. (1964). Principles of psychological measurement. New York: AppletonCentury-Crofts.

Ivancevich, J. M. Napier, H. A. \& Wetherbe, J. C. (1983). Occupational stress, attitudes and health problems in the Information system personnel. Communication of the ACM, 26(10), 800-806.

Ivancevich, J.M., Napier, H. A. \& Wetherbe, J. C. (1985).An empirical study of occupational stress, attitudes and health among information system personnel. Information Management, 9, 77-85.

Koh, Chee Seng (1990). Occupational stress and health among IT professionals in Singapore. Unpublished master's dissertation, National University of Singapore.

Latack, J. C. (1986). Coping with stress: Measures and future directions for scale development. Journal of Applied Psychology, 71(3), 377-385.

Lazarus, R. S. \& Folkman, S. (1984). Stress, appraisal and coping. New York: Spinger.

Lazarus, R.S. (1991). Psychological stress in the work place. In P. L. Perrewe (Ed.), Handbook on job stress. Journal of Social Behaviour and Personality, 6, 1-13.

Liang, Ai Hua (1997). Occupational stress among IT professionals in Singapore. Unpublished master's dissertation, National University of Singapore.

Malaysia. (2001). The third outline perspective plan 2001-2010. Economic Planning Unit,
Kuala Lumpur: Percetakan Nasional Berhad.

Mohd Hasan Selamat. (1994). Occupational stress and health problems among the information personnel in the government. Proceedings of the International Conference on Information Technology, Gabungan Komputer Nasional Malaysia, Kuala Lumpur, August 9 -12.

Monat, A. \& Lazarus, R. S. (1977). Stress and coping: An analogy. New York: Columbia University Press.

Ong, Hian Leong. (1992). A study of burnout among IT professionals. Unpublished master's dissertation, National University of Singapore.

Payne, R. L., Fineman, S. \& Wall, T. D. (1988). Organizational climate and job satisfaction: A conceptual synthesis. Organizational Behaviour and Human Performance, 16.

Pearlin, L. I. \& Schooler, C. (1978). The structure of coping: An analogy. New York: Columbia University Press.

Selye, H. (1976). The stress of life. New York: McGraw Hill.

Thi, L.S. (2001). A survey on stress coping strategies among ICT personnel. Unpublished manuscript, School of Management, Universiti Utara Malaysia, Sintok.

Ungku Norulkamar Ungku Ahmad. (1995). Job stress and coping strategies. Malaysian Management Review, 30 (1), 16-25.

Weiss, M. (1983). Effects of work stress and social support on information system managers. MIS Quarterly, March, 29-43. 


\section{APPENDIX A}

Convenience sampling is used. Respondents are confined to ICT personnel working in private organizations. They include computer programmers, system/hardware engineers, software developers, business/system analysts and other ICT personnel who provided technical support. Two hundred and ten questionnaires containing cover letters and survey instruments were distributed to ICT personnel employed in companies dealing with IT products and services in Kuala Lumpur. Out of the 210 questionnaires, 102 were returned. Four questionnaires were not usable due to incomplete responses. A total of 98 questionnaires were included in the final analysis, thus constituting a usable response rate of 46.7 percent.

The survey consists of a four-page questionnaire. It is divided into four sections. Respondents were asked to answer questionnaires containing measurement for behaviour patterns, coping techniques, measurement for work stress and personal biodata of the respondents.

Items measuring the variables in this study are derived from review of literature on work stress coping strategies. Multiple items scales are used to tap constructs wherever possible. The measurement instrument of personality type is adopted from Bortner's (1969) Pattern A Behaviour Scale (PABS). This scale is chosen as it is one of the most widely validated, comprehensive and short scales of personality type inventories. This measure consists of 13 items on a 5-point scale.

The measurement of coping strategies uses are 32-items instruments developed by Latack (1986) and adopted locally by Ungku Norulkamar (1995). Three types of coping strategies are used that is, control, escape and symptom-management strategies. The control strategy displays proactive and take-charge attitude while the escape strategy shows escapist and avoidance mode. Symp- tom-management strategy refers to the management of symptoms related to occupational stress such as meditation, exercise, relaxation or seeking professional help such as counseling. The control strategy comprises 16 items, 10 symptommanagement strategy items and 6 escape strategy items. Each item in the scale is anchored by a fivepoint Likert scale.

The General Physical Health Questionnaire as a criterion of measuring physical health is used in this research. The respondents are required to mark the frequency of the 15 symptoms of illhealth which they have experienced during the last three months based on a five-point Likert scale.

\section{APPENDIX B}

\section{Coping Strategy Dimensions}

In order to determine the key dimensions of coping strategies, factor analyses are performed. Items with low factor loadings of below 0.5 are eliminated and subsequent factor analyses are carried out. The final factors analyses are based on the criterion that two or more variables with factor loadings of 0.5 or more and cumulative variance explained about $50 \%$ of the variance. Principalcomponent analysis is utilized so that a set of associated variables portrayed in terms of a set of mutually correlated (orthogonal) linear combinations of the variables are extracted. As a result 11 factors are extracted initially. The fifth analyses result in five interpretable factors that explain $56.663 \%$ of the variance (see Table B1).

In order to ensure that items comprising each factor are internally consistent, reliability assessment is performed using Cronbach alpha. The Cronbach alpha for all the five dimensions of coping strategies are equal to or above the recommended value of 0.5 for exploratory research. Results of factor analysis are shown in Table B2. 
Table B1

Factorial Dimensions of Coping Strategies and Factor Loadings

Factorial dimensions of coping strategies and items

Loadings

\section{Factor 1 : Face challenges}

$($ Eigenvalue $=3.575$ Var $=18.815 \%$ Alpha $=.84)$

24 Pay more attention to my work and work harder

.757

14 Devote more time and energy in doing my job

10 Put extra effort on planning and scheduling

9 Try to see situation as an opportunity to learn and develop new skills

4 Try to be very organized so that I can keep on top of things.

21 Give my best effort to do what I think is expected of me.

\section{Factor 2 : Physical and emotional relief}

$($ Eigenvalue $=2.092$ Var $=11.008 \%$ Alpha $=.64)$

26 Indulge in physical exercise

28

Watch TV or movie or listen to music

Have extra sleep or nap

29 Go shopping or go for holiday

Factor 3 : Escape from situation

$($ Eigenvalue $=1.813 \mathrm{Var}=9.542 \%$ Alpha $=.51)$

3 Tell myself that time will take care of stressful situation like this

12 Separate myself as much from the people who created this situation

32 Turn to prayer or meditate.

\section{Factor $4:$ Seek treatment}

$\overline{(\text { Eigenvalue }=1.769 \mathrm{Var}}=9.311 \%$ Alpha $=.79)$

30 Attend stress management training

31 Go for counseling or seek professional help

Factor 5: Ignore the situation

$($ Eigenvalue $=1.518 \mathrm{Var}=7.987 \%$ Alpha $=.57)$

17 Accept the situation because there is nothing I can do to change it.

7 Remind myself that work isn't everything

Note : The five factors explained $56.663 \%$ of cumulative variance and extraction sum of squared loadings Overall Cronbach Alpha 7204

Factor one, explaining $18.82 \%$ of the variance is labelled "Face Challenges". Examples of items forming factor 1 include "Pay more attention to my work and work harder", "Devote more time and energy in doing my job" and "Put extra effort on planning and scheduling”. Factor two comprises of items which dealt with seeking relief. This factor is labelled "Physical and Emotional Relief", and accounted for $11.01 \%$ of the common variance. Items which loaded onto this 
factor include "Indulge in physical exercise", "Watch TV or movie or listen to music", "Have extra sleep or nap". Factor three comprises of items that indicate escaping from the situations. This factor is accounted for $9.54 \%$ of the variance. Factor four accounts for $9.31 \%$ of the variance and is labelled 'Seek Treatment'. Items in this dimensions include "Attending stress management training" and "Go for counselling or seek professional help". Finally factor five, accounts for $7.99 \%$ of the variance, and is labelled "Ignore the Situation or Do Nothing". Items which loaded on this factor include "Accept the situation because there is nothing I can do to change it" and "Remind myself that work isn't everything". Results of reliability test using Cronbach Coefficient Alpha to measure the consistency and stability of the constructs of the five dimensions based on Helmstadter's (1964) standard of 0.5 are shown in Table B2.

Table B2

Internal Reliability Coefficients of the Scale

\begin{tabular}{|lcc|}
\hline Scale & \# of items & Cronbach Alpha \\
\hline Face challenges & 7 & .84 \\
Physical and emotional relief & 4 & .65 \\
Escape from situation & 3 & .51 \\
Seek treatment & 2 & .79 \\
Ignore the situation/Do Nothing & 2 & .57 \\
\hline
\end{tabular}

\section{APPENDIX C}

Definition and Measurement of Variables Used in Probit Model:

\begin{tabular}{|c|c|c|}
\hline Variables & Definition & Measurement \\
\hline Stress 00 & Work stress & $\begin{array}{l}0 \text { if mild stress } \\
1 \text { if moderate stress }\end{array}$ \\
\hline Dtype & Personality type & $\begin{array}{l}0 \text { if type } A \\
1 \text { if type } B\end{array}$ \\
\hline channll1 & Face challenges coping strategy & $\begin{array}{l}1=\text { never; } 2=\text { seldom; } 3=\text { sometimes; } \\
4=\text { very often; } 5=\text { almost all the time }\end{array}$ \\
\hline relief & Physical \& emotional relief coping strategy & $\begin{array}{l}1=\text { never; } 2=\text { seldom; } 3=\text { sometimes; } \\
4=\text { very often; } 5=\text { almost all the time }\end{array}$ \\
\hline escape 1 & Escape from situation coping strategy & $\begin{array}{l}1=\text { never; } 2=\text { seldom; } 3=\text { sometimes; } \\
4=\text { very often; } 5=\text { almost all the time }\end{array}$ \\
\hline
\end{tabular}


(continued)

\begin{tabular}{|c|c|c|}
\hline Variables & Definition & Measurement \\
\hline treatm1 & Seek treatment coping strategy & $\begin{array}{l}1=\text { never; } 2=\text { seldom; } 3=\text { sometimes; } \\
4=\text { very often; } 5=\text { almost all the time }\end{array}$ \\
\hline ignore1 & Ignore the situation coping strategy & $\begin{array}{l}1=\text { never } ; 2=\text { seldom } 3=\text { sometimes; } \\
4=\text { very often; } 5=\text { almost all the time }\end{array}$ \\
\hline $\begin{array}{l}\text { typeCh1 } \\
\text { typeRel } \\
\text { typeEsc } \\
\text { typeTm } \\
\text { typeIg }\end{array}$ & $\begin{array}{l}\text { Interactive variable between Dtype and channll1 } \\
\text { Interactive variable between Dtype and relief } \\
\text { Interactive variable between Dtype and escape1 } \\
\text { Interactive variable between Dtype and treatm1 } \\
\text { Interactive variable between Dtype and ignore1 }\end{array}$ & \\
\hline Dethnic & Ethnic & $\begin{array}{l}0 \text { if Malay } \\
1 \text { if non-Malay }\end{array}$ \\
\hline Dgender & Gender & $\begin{array}{l}0 \text { if Male } \\
1 \text { if Female }\end{array}$ \\
\hline Dmar1-2 & Dummy variable for marital status & $\begin{array}{l}\text { Dmar } 1=1 \text { if married without } \\
\text { children } \\
\text { Dmar } 2=1 \text { if married with children } \\
\text { Dmar } 1-2=0 \text { if single }\end{array}$ \\
\hline Dfield1-2 & Dummy variable for field of specialization & $\begin{array}{l}\text { Dfield } 1=1 \text { if science/IT } \\
\text { Dfield2 }=1 \text { if engineering } \\
\text { Dfield } 1-2=0 \text { if accounting/business/ } \\
\text { economics }\end{array}$ \\
\hline Djobs1-3 & Dummy variable for job status & $\begin{array}{l}\text { Djob1=1 if executive } \\
\text { Djob2=1 if middle management } \\
\text { Djob3 }=1 \text { if senior management } \\
\text { Djob1-3=0 if junior management }\end{array}$ \\
\hline yrwork & Year of working experience groups & $\begin{array}{l}1=\text { less two years } \\
2=\text { three to six years } \\
3=\text { seven to ten years } \\
4=\text { more than ten years }\end{array}$ \\
\hline Dserve1-3 & Dummy variable for length of service & $\begin{array}{l}\text { Dserve1 }=1 \text { if three to six years } \\
\text { Dserve2 }=1 \text { if seven to ten years } \\
\text { Dserve3 }=1 \text { if more than ten years } \\
\text { Dserve1-3=0 if less than or equal } \\
\text { to two years }\end{array}$ \\
\hline
\end{tabular}


(continued)

\begin{tabular}{|c|c|c|}
\hline Variables & Definition & Measurement \\
\hline edu & Education level & $\begin{array}{l}1=\mathrm{SPM} / \mathrm{MCE} / \mathrm{GCE} \\
2=\mathrm{STPM} / \mathrm{HSC} / \mathrm{A} \text { level } \\
3=\text { Diploma } \\
4=\text { Bachelor degree or equivalent } \\
5=\text { master } \\
6=\mathrm{PhD}\end{array}$ \\
\hline Dage1-5 & Dummy variable for age groups & $\begin{array}{l}\text { Dage } 1=1 \text { if } 25-30 \\
\text { Dage } 2=1 \text { if } 31-35 \\
\text { Dage3 }=1 \text { if } 36-40 \\
\text { Dage4 }=1 \text { if } 41-50 \\
\text { Dage5 }=1 \text { if }>50 \\
\text { Dage } 1-5=0 \text { if }<25\end{array}$ \\
\hline
\end{tabular}

\section{APPENDIX D}

Probit estimates

Number of obs $=98$

Wald chi2(28) $=52.81$

Prob $>$ chi2 $=0.0031$

Log likelihood $=-25.104455$

Pseudo R2 $=0.4244$

\begin{tabular}{lrrrrrr}
\hline \multicolumn{2}{c}{ Robust } & & & & \\
stress00 & \multicolumn{1}{c}{ Coef. } & Std.Err. & $\mathrm{z}$ & $\mathrm{P}>|\mathrm{z}|$ & \multicolumn{1}{c}{$[95 \%$ Conf. Interval] } \\
\hline Dtype $\mid$ & .3942835 & 3.037428 & 0.130 & 0.897 & -5.558966 & 6.347533 \\
chanl11 | & .1188527 & .5169009 & 0.230 & 0.818 & -.8942544 & 1.13196 \\
relief $\mid$ & -.3904667 & .3731857 & -1.046 & 0.295 & -1.121897 & .3409639 \\
escape1 | & 1.425115 & .7022676 & 2.029 & 0.042 & .0486958 & 2.801534 \\
treatm1 | & -1.159211 & .5463788 & -2.122 & 0.034 & -2.230093 & -.0883279 \\
ignore1 | & -.2876684 & .4875789 & -0.590 & 0.555 & -1.243306 & .6679687 \\
typeCh1 | & .3882352 & .6104395 & 0.636 & 0.525 & -.8082043 & 1.584675 \\
typeRel | & .0007377 & .4741828 & 0.002 & 0.999 & -.9286435 & .930119 \\
typeEsc $\mid$ & -1.392867 & .7177222 & -1.941 & 0.052 & -2.799577 & .0138424 \\
typeTm | & 1.132355 & .7381204 & 1.534 & 0.125 & -.3143342 & 2.579045 \\
typeIg $\mid$ & .1114253 & .594472 & 0.187 & 0.851 & -1.053718 & 1.276569 \\
Dethnic $\mid$ & 1.415813 & .6892834 & 2.054 & 0.040 & .0648427 & 2.766784 \\
Dgender | & -.3469439 & .6112833 & -0.568 & 0.570 & -1.545037 & .8511493 \\
Dmar1 | & .6041926 & .6335354 & 0.954 & 0.340 & -.637514 & 1.845899 \\
Dmar2 | & 2.632279 & .8376659 & 3.142 & 0.002 & .990484 & 4.274074 \\
\hline
\end{tabular}


(continued)

\begin{tabular}{lrrrrrr}
\hline \multicolumn{2}{c}{ Robust } & & & & \\
stress00 & \multicolumn{1}{c}{ Coef. } & Std.Err. & \multicolumn{1}{c}{$\mathrm{z}$} & $\mathrm{P}>|\mathrm{z}|$ & \multicolumn{1}{c}{$[95 \%$ Conf. Interval] } \\
\hline Dfield1 | & -1.240367 & .5773499 & -2.148 & 0.032 & -2.371952 & -.1087818 \\
Dfield2 | & -.3039402 & .8212803 & -0.370 & 0.711 & -1.91362 & 1.30574 \\
Djobs1 | & .8207724 & .6849542 & 1.198 & 0.231 & -.5217132 & 2.163258 \\
Djobs2 | & -.5926514 & .50977 & -1.163 & 0.245 & -1.591782 & .4064794 \\
Djobs3 | & -1.587546 & .7888126 & -2.013 & 0.044 & -3.13359 & -.0415018 \\
yrswork | & .2574951 & .3182712 & 0.809 & 0.418 & -.3663051 & .8812952 \\
Dserv1 | & -1.857432 & .6526436 & -2.846 & 0.004 & -3.13659 & -.5782743 \\
Dserv3 | & -2.966736 & 1.053191 & -2.817 & 0.005 & -5.030953 & -.9025191 \\
edu $\mid$ & .1365569 & .2352775 & 0.580 & 0.562 & -.3245785 & .5976923 \\
Dage1 | & .6196436 & .5995563 & 1.034 & 0.301 & -.5554653 & 1.794752 \\
Dage2 | & 1.284302 & .9130199 & 1.407 & 0.160 & -.5051846 & 3.073788 \\
Dage3 | & .4727321 & .8486023 & 0.557 & 0.577 & -1.190498 & 2.135962 \\
Dage4 | & -.6525165 & 1.146976 & -0.569 & 0.569 & -2.900549 & 1.595516 \\
cons $\mid$ & .3704324 & 2.582246 & 0.143 & 0.886 & -4.690677 & 5.431542 \\
& & & & & & \\
\hline
\end{tabular}

